\title{
Prognostic factors for the outcome of childhood asthma in adolescence
}

\author{
Ruurd Jan Roorda
}

The incidence of asthma, particularly in childhood, is rising. ${ }^{1-4}$ Although the precise reasons for this increase are unknown, it is likely that a number of environmental factors are at least partly responsible. To date, the most likely explanation for the increased prevalence of asthma is an increased allergen load in the environment causing increased airway responsiveness in atopic children. ${ }^{5}$ The increased prevalence of asthma in children may well have serious implications for adults if patients continue to have asthma symptoms in adulthood, although, as yet, only a small number of studies have shown that the prevalence of asthma rises in young adults. ${ }^{6}$

Over the past few decades the natural evolution of asthma from childhood to adulthood has been the subject of many studies. ${ }^{7-57}$ It was long believed that the prognosis for asthma originating in infancy or childhood was good, and that in most patients the symptoms would resolve by the age of puberty. However, a review of the literature shows that not all patients become asymptomatic in adulthood. In fact, asthma symptoms persist in $30-80 \%$ of adult patients. Although epidemiological studies have shown a fair chance of either "remission" or a reduction in asthma symptoms between the ages of 10 and 20 years, ${ }^{58-61}$ and most population based and clinical studies have also shown a reduction in asthma symptoms with age, the relapse rate after a symptom-free interval is known to be relatively high. ${ }^{6062}$ It has also been shown that, even in the absence of asthma symptoms, subjects may still have obstructed air flow limitation and increased bronchial responsiveness. ${ }^{3963-66}$

A number of questions therefore remain to be answered:

1. Can childhood asthma really be outgrown?

2. Do asthmatic children become asthmatic adults?

3. Will the rise in childhood asthma lead to a further increase in the incidence of asthma in the adult population?

4. Which factors determine the prognosis of asthma in individual children?

Furthermore, certain risk factors which could probably be recognised in childhood might be associated with an unfavourable prognosis. If this is the case, treatment and medical supervision of children at risk should start at an early age. Can such treatment affect the prognosis of childhood asthma?

Most published studies are retrospective in design (questionnaire based studies) and have therefore been subject to potential bias due to missing data, loss to follow up, and recall bias. ${ }^{6768}$ Relatively few prospective studies have focused on childhood factors which may contribute to the prediction of outcome in adulthood.

\section{Definition of asthma}

A review of the literature highlights the fact that in most studies asthma is not clearly defined. Unfortunately, many physicians are reluctant to make a diagnosis of asthma in infants, preferring to use terms such as "wheezy bronchitis". Children who are classified as having "wheezy bronchitis" in one study may well be diagnosed asthmatic in another study. The absence of a uniform definition of asthma makes the available data difficult to interpret.

\section{Population under study}

Another problem is the selection and heterogeneity of subjects for studies on the long term prognosis of asthma. Most of these studies have been based on selected groups of patients with moderate or severe asthma. However, population based cohort studies indicate that the prognosis of mild asthma is probably much more favourable. It is therefore important to realise that potential risk factors that might affect the outcome of childhood asthma are directly related to the population under study and the severity of disease.

\section{Length of follow up}

A further problem in the study of long term prognosis of asthma is the relatively short periods of observation employed in many studies. Asthma may vary spontaneously over time and periods of remission are often followed by relapses. An important problem, therefore, is that of "complete remission" which has been defined as complete freedom from asthma symptoms during a period of between two and five years, or the absence of symptoms at the time of the final assessment. It is now well known that asthma symptoms may recur after much longer periods of time. It is therefore likely that a considerable number of patients thought to be in complete remission remain latent asthmatics until the symptoms are triggered again.

\section{Potential risk factors}

Notwithstanding these limitations, it has been suggested in the literature that a number of factors influence asthma prognosis including family history of atopy, age of onset of symp- 
toms and asthma severity in childhood, childhood respiratory infections, sex, presence of other atopic conditions such as eczema or allergic rhinitis, and exposure to allergens and other environmental triggers such as tobacco smoke and damp. Prospective studies that include a measure of childhood pulmonary function and bronchial responsiveness and data on allergy (as assessed by skin tests or radioallergosorbent test (RAST)) are limited and have only been published in recent years.

\section{Clinical studies}

ONSET OF ASTHMA AND ITS SEVERITY IN CHILDHOOD

The majority of clinical studies do not show a significant negative effect on the prognosis of early onset asthma although the disease may be severe in these children. ${ }^{121321274351}$ In some studies early onset of symptoms has been associated with an unfavourable outcome..$^{203554}$ This does not contradict the favourable prognosis for children with wheezing during the early years of life found in epidemiological studies since this group of patients includes a number of children with wheezy illnesses other than asthma. A higher asthma symptom score in childhood, which represents more severe asthma, is a well known risk factor for the persistence of asthma in adulthood. ${ }^{1727351}$ The clinical severity of asthma in childhood is therefore an important predictor of asthma persistence in adulthood.

\section{ATOPIC MANIFESTATIONS}

In at least $75 \%$ of asthmatic children asthma is associated with allergy to inhaled allergens and a family history of allergy.

Few long term studies have considered the influence of family history on the long term prognosis of childhood asthma. Ryssing and Flensborg ${ }^{18}$ and Martin et $a l^{31}$ agree that a positive family history for atopy is associated with an unfavourable asthma prognosis. However, in other studies family history was found not to affect asthma prognosis adversely. ${ }^{253447}$

If family history does not determine individual asthma prognosis the implication is that the severity of asthma is not genetically determined, even if the individual has a genetic predisposition to the disease. Therefore, environmental factors are probably the most important factors in the clinical expression and prognosis of asthma.

Due to cumulative exposure to allergens, skin reactivity to inhaled allergens increases with age and peaks in young adults aged between 25 and 34 years of age ${ }^{69}$ Many studies have shown that both the number of positive skin tests and weal diameter increase with age. In most of the studies the increase in skin reactivity, as expressed by the number of positive skin tests, appears to be independent of the progress of asthma in children. ${ }^{24273070}$ Some studies have shown a favourable prognosis in children with negative skin tests or positive tests to a small number of allergens. ${ }^{43}$ These findings might, however, be influenced by se- lection criteria, as almost all of the children included in these studies were allergic.

In our own study, in which the study population was stratified according to the degree of skin reactivity in childhood (sum score of the semiquantitative expression of weal diameters), those subjects who had the lowest childhood total skin test score were found to have the lowest incidence of asthma symptoms in adulthood. Mean eosinophil count in childhood was slightly but not significantly higher in subjects with persistent symptoms in adulthood. ${ }^{450}$

Mazon $e t a l^{55}$ studied the effects of sensitivity to allergens (as assessed by skin testing or RAST) on the persistence of asthma. Although the follow up interval was rather short (mean 63 months) and the ages of the children included in the study were not given, a significant association with persistent symptoms and sensitisation to house dust mite, moulds, pollen, and milk protein was demonstrated.

No data are available to date on the value of either total or specific serum IgE levels in the assessment of asthma prognosis. In some studies children with normal or only slightly raised IgE values ("intrinsic asthma") were labelled as having the most troublesome disease. ${ }^{3437}$

Although epidemiological studies suggest that the presence of allergic eczema and/or rhinitis with asthma has a negative effect on asthma prognosis, ${ }^{4871}$ clinical studies have proved to be inconclusive. Some studies found no predictive effect, ${ }^{46525572}$ while others showed a significant negative effect of atopic eczema on asthma prognosis. ${ }^{111819262744}$

\section{BRONCHIAL HYPERRESPONSIVENESS}

A relationship exists between atopy or specific (allergic) bronchial hyperresponsiveness and non-specific bronchial hyperresponsiveness to, for example, histamine or methacholine. However, although atopy and bronchial hyperresponsiveness are interrelated, they appear to act independently with respect to asthma prognosis.

Gerritsen $^{46}$ studied the prognostic value of the type of response to specific (house dust) inhalation provocation in childhood. The study indicated that the prognosis for subjects who had no response in childhood was better than for those subjects who did exhibit a response. However, there were no significant differences in the prognosis for children with either an early, late, or dual asthmatic response.

Non-specific bronchial hyperresponsiveness may presage asthma. ${ }^{737}$ The degree of nonspecific bronchial hyperresponsiveness may vary greatly from time to time within the asthmatic individual. As the asthmatic child matures bronchial responsiveness may decrease. The cause of the decrease is not known but may be due to a number of reasons such as hormonal and structural changes associated with growth. ${ }^{75}$ This has led to speculation that a natural decrease in bronchial responsiveness may be responsible for the improvement of asthma in adolescence. ${ }^{76}$ Although bronchial responsiveness in asthmatic children decreases with age, in the majority of clinical studies 
approximately half of symptomatic young adults remained hyperresponsive. In subjects with no symptoms in adulthood the proportion who remained hyperresponsive was much lower. ${ }^{46515662}$

In prospective studies employing multiple regression techniques the degree of childhood bronchial hyperresponsiveness was one of the few significant variables that predicted persistent symptoms in adulthood. ${ }^{451}$ Furthermore, a strong association was found between the presence and degree of bronchial hyperresponsiveness and the need for medication in adulthood. Treatment of airway inflammation, reflected by bronchial hyperresponsiveness, is fundamental, ${ }^{77}$ and such treatment may also have a positive effect on the long term prognosis of the disease.

\section{It is a common belief that the airways obstruction of childhood asthma is reversible.}

\section{PULMONARY FUNCTION}

It is a common belief that the airways obstruction of childhood asthma is completely reversible. However, in recent years numerous studies have demonstrated persistent pulmonary abnormalities in both children and adults. ${ }^{3963-66}$ It therefore seems necessary not only to treat symptomatic episodes of asthma in childhood but also to optimise pulmonary function on a long term basis and to minimise the process that may relate to irreversible airways obstruction.

Since pulmonary function in most children with asthma is thought to be normal, it follows that persistent abnormal pulmonary function in childhood (measured either at rest or after treatment with bronchodilating agents, which compensate for the reversible part of the disturbance of pulmonary function) is probably associated with more severe asthma and an unfavourable prognosis.

A number of studies have shown that the level of childhood pulmonary function is indeed predictive of persistent asthma symptoms in adulthood. ${ }^{3840}$ Although other studies do not confirm these findings they do demonstrate the predictive value of a combination of airway responsiveness and levels of forced expiratory volume in one second $\left(\mathrm{FEV}_{1}\right){ }^{51}$ Most of the studies published to date do show a strong correlation between the level of pulmonary function in childhood and adulthood. ${ }^{384052}$ In asymptomatic adults the percentage predicted $\mathrm{FEV}_{1}$ was in the normal range (or became closer to normal the longer the patient was free of wheezing), ${ }^{526578}$ while their childhood level was normal or only mildly reduced. In an Australian follow up study subjects who still had severe symptoms in adulthood had the most serious disturbance of pulmonary function in childhood and the steepest decline of pulmonary function towards adulthood. $\mathrm{FEV}_{1}$ levels below the fifth percentile at 10 or 14 years of age were associated with more troublesome asthma at the age of 21 years. $^{38}$

\section{Studies in children consistently show a higher prevalence of asthma in boys..., but in general the prognosis for women is worse than it is for men.}

DIFFERENCES IN SEX WITH RESPECT TO ASTHMA Studies in children consistently show a higher prevalence of asthma in boys, the prevalence before puberty being at least twice as high in boys than in girls. Symptoms may also start at a younger age in boys.

The higher prevalence of asthma in boys may be caused by a combination of factors. "Host susceptibility" may be greater in boys, and a higher incidence of respiratory distress syndrome and other respiratory illnesses suggest that boys may have more vulnerable airways. The absolute peripheral airway diameter is smaller in young boys than it is in young girls, especially in the first 18 months of life. ${ }^{7980}$ Differences in the prevalence of asthma may also be influenced by differences in the size of the airways relative to size of the lungs. The prevalence of allergic phenomena is also higher in boys. ${ }^{451}$ Furthermore, some studies have demonstrated a higher prevalence of bronchial hyperresponsiveness in boys. ${ }^{82-84}$

The predominance of boys among asthmatic subjects gradually diminishes until puberty when a higher incidence of new cases of asthma is found in girls, ${ }^{28}$ and after the age of 20 years the incidence of asthma is higher in women than in men. In most studies in young asthmatic adults the male:female ratio is about $1: 1 \cdot 5$. Hospital admission rates and morbidity rates after the age of 40 years are also significantly higher in women than in men. Not only is the proportion of women with current complaints in adulthood higher than in men, symptom scores are also increased. In general, therefore, the prognosis for women is worse than it is for men. ${ }^{1284044518586}$ The cause of the differences between the sexes is unknown and it is somewhat surprising that this topic is not addressed more fully in the literature.

In the 1960s it was postulated that hormonal differences might be responsible for the differences in asthma severity between the sexes. ${ }^{87}$ Hormones may influence airway inflammation, airway smooth muscle function, and vascular integrity. The higher levels of morbidity due to asthma in women may also be related to differences in the rate of lung growth between the sexes and a deterioration of pulmonary function with age. Airway diameter and parenchymal size may also affect morbidity due to asthma as airway responsiveness is related to airway size. Women possess smaller lungs than men and this may explain their increased airway responsiveness, although the higher level of airway responsiveness cannot completely explain the higher level of morbidity due to asthma among women. 
SMOKING

Both active and passive smoking influence the outcome of childhood asthma. However, few long term clinical studies have been carried out on the influence of passive smoking on the prognosis of asthma in children. There is evidence that a substantial proportion of children with asthma, especially boys, have worsening symptoms and reduced pulmonary function when passively exposed to tobacco smoke. ${ }^{88}$

The effects of passive smoking is likely to be more significant in population based studies than in clinical studies. Tager ${ }^{89}$ demonstrated that inhaled smoke, either actively or passively, renders asthmatic children more susceptible to irreversible limitation of the small airways.

However, two prospective studies in young adults in the Netherlands found no significant effects on asthma symptoms among active smokers, ${ }^{4051}$ although in one of the studies the cigarette smoking (as measured by the number of pack years) adversely affected the $\mathrm{FEV}_{1}$ levels in adult men. ${ }^{51}$ The lack of negative health effects may be explained by the so-called "healthy smoker" effect in which mildly asthmatic individuals with relatively few symptoms and limited bronchial responsiveness are able to start cigarette smoking. The proportion of asthmatics who were active smokers was surprisingly high compared with the proportion of smokers in the Dutch population as a whole. However, neither of these studies included a sufficiently long follow up period and the number of pack years was too small to demonstrate all of the potential effects of cigarette smoking on the prognosis for asthma sufferers. ${ }^{90}$ The same limitations may explain the lack of a negative effect of cigarette smoking found in the Australian follow up study. ${ }^{38}$

\section{TREATMENT}

Asthma is considered to be an inflammatory disease of the airways and anti-inflammatory agents are currently the mainstay of asthma treatment. Few long term studies on the influence of such treatment on asthma prognosis have been published. A large prospective multicentre study in 116 children compared treatment for 22 months with either budesonide in combination with salbutamol (each $600 \mu \mathrm{g}$ daily), or salbutamol and placebo. Children who received inhaled corticosteroids showed a significant reduction in asthma symptoms within the first few months of the study, a slight increase in pulmonary function, and a reduction in airway responsiveness which still had not reached a plateau by the end of the study. ${ }^{91}$ In some of the children asthma symptoms had resolved (clinical remission for at least eight months). Lower symptom burden at baseline seemed to be the only predictor of patients likely to enter remission..$^{92}$ However, cessation of inhaled corticosteroid therapy led to recurrence of symptoms and a rapid deterioration of airway responsiveness. ${ }^{93}$ It may be concluded, therefore, that inhaled corticosteroid therapy cannot cure asthma, and that the underlying inflammatory process remains, even after a long period of treatment.

In a retrospective study carried out in Denmark maintenance prophylactic treatment with inhaled corticosteroids was compared with other treatment regimens in children. The study indicated that the earlier treatment with corticosteroids was begun following the diagnosis of asthma, the greater was the increase in pulmonary function $\left(\mathrm{FEV}_{1}\right.$ ml/year). ${ }^{94} \mathrm{König}^{95}$ carried out a retrospective study to compare the effects of sodium cromoglycate with those of inhaled corticosteroids. A significant clinical improvement and improvement in pulmonary function were found in all of the children treated with anti-inflammatory agents, and there were no differences between agents. As properly matched and controlled prospective long term studies have not yet been published, it is not possible to evaluate the effects of any particular treatment for asthma. Nevertheless, the above studies suggest that early use of prophylactic asthma treatment may succeed in improving the prognosis for asthmatic children and may favour optimal lung growth throughout adolescence.

\begin{tabular}{c}
\hline ... denial of symptoms is \\
characteristic of adolescents with \\
asthma.
\end{tabular}

\section{UNDER-DIAGNOSIS AND UNDER-TREATMENT}

Although the prevalence of asthma is rising worldwide, there is still evidence for underdiagnosis of asthma in childhood. ${ }^{96}$ In addition, patients may frequently underestimate the severity of their disease and denial of symptoms is characteristic of adolescents with asthma. Both of these factors imply a risk of the disease not being appropriately treated.

Studies have shown that, although the proportion of young adults who continue to suffer from asthma symptoms is relatively high, the number of them who are under medical supervision for their asthma is low. The majority (approximately $80 \%$ ) do not receive regular medical supervision, though these individuals may have a high symptom score. ${ }^{4951}$ Fortunately, the more severe the asthma, the greater the proportion of subjects who do receive regular monitoring.

Most adolescents included in these studies exhibited poor compliance with their treatment regimens and this may mean that they received either inadequate treatment or no treatment at all. In the follow up cohort study carried out in Australia more than $75 \%$ of patients aged 21 years who had frequent episodes of asthma and $40 \%$ of those with persistent asthma were not receiving adequate treatment. ${ }^{97}$ Despite the presence of asthma symptoms, the majority of patients did not use any medication for their asthma. Those who did used mainly bronchodilator therapy, and only a minority received anti-inflammatory treatment. ${ }^{495156}$ 


\section{Conclusion}

By the second decade of life asthma symptoms often abate and it may seem that patients with mild asthma have "outgrown" the disease. Unfortunately this is likely to be the exception rather than the rule.

Although the severity of asthma symptoms fluctuates with time, the inherited tendency towards respiratory symptoms never disappears and many teenagers who seem to be free of symptoms do, in fact, have persistent asthma. During symptom-free periods subclinical, but nevertheless significant, airways obstruction and/or bronchial hyperresponsiveness may be present. It is not unusual for adults who have been asymptomatic for a number of years to redevelop asthma symptoms. Indeed, much of the so-called adult onset asthma has its roots in childhood. Levison ${ }^{98}$ concluded that, in these subjects, it is often not the asthma that is outgrown but the paediatrician.

\section{... it is often not the asthma that is outgrown but the paediatrician.}

The more severe asthma is in childhood the more likely it is that the disease will persist in adulthood. A complete list of the characteristics of the disease in childhood, and the potential risk factors associated with an unfavourable prognosis, such as pulmonary function and bronchial responsiveness and markers of airway inflammation, is therefore needed.

As properly matched and controlled prospective long term studies have not been published it has not been possible to evaluate the effects on prognosis of any single class of antiasthma agent. Such studies are needed to find out if it is possible to alter the natural history of the disease. In theory modern asthma treatments, because they are able to improve symptoms and underlying disease phenomena, are also beneficial in the long term prognosis of childhood asthma.

\section{Since compliance ... is low, a monitoring system is needed to guarantee adequate follow up and treatment during and beyond puberty.}

The majority of patients with persistent asthma included in the currently available studies were not receiving adequate treatment. Since compliance with therapeutic regimens in asthma, especially in adolescence, is low, a monitoring system is needed to guarantee adequate follow up and treatment during and beyond puberty.

1 Robertson CF, Heycock E, Bishop J, Nolan T, Olinsky A Phelan PD. Prevalence of asthma in Melbourne schoolchildren: changes over 26 years. BMF 1991;302:1116-8.

2 Peat JK, van den Berg RH, Green WF, Mellis CM, Leeder SR, Woolcock AI. Changing prevalence of asthma in Australian schoolchildren. BMf 1994;308:1591-6.
3 Anderson HR, Butland BK, Strachan DP. Trends in prevalence and severity of childhood asthma. BMF 1994;308: valence and $1600-4$.

4 Whincup PH, Cook DG, Strachan DP, Papacosta O. Time trends in respiratory symptoms over a 24 year period. Arch Dis Child 1993;68:729-34.

5 Cullinan P, Newman Taylor AJ. Asthma in children: environmental factors. BMF 1994;308:1585-6.

6 Peat JK, Haby M, Spijker J, Berry G, Woolcock AJ. Prevalence of asthma in adults in Busselton, Western Australia. $B M F$ 1992;305:1326-9.

7 Flensborg E. The prognosis for bronchial asthma arisen in infancy after the non-specific treatment hitherto applied. Acta Paediatr (Uppsala) 1945;33:5-24.

8 Rackemann FM, Edwards M. Asthma in children. A followup study of 688 patients after an interval of 20 years. $N$ Engl f Med 1952;246:815-23.

9 Rackemann FM, Edwards M. Asthma in children. A followup study of 688 patients after an interval of twenty years (concluded). $N$ Engl $f$ Med 1952;246:858-63.

10 Dees SC. Development and course of asthma in children. Am $\mathcal{f}$ Dis Child 1956;93:228-33.

11 Harnack GA, Panten H. Asthma bronchiale im kindesalter. Mschr Kinderheilk 1957;105:255-8.

12 Ryssing E. Continued follow-up investigation concerning the fate of 298 asthmatic children. Acta Paediatr (Uppsala) 1959;48:255-60.

13 Harnack GA, Wagemann M. Asthma bronchiale im Kindesalter. Mschr Kinderheilk 1960;108:491-3.

14 Ogilvie AG. Asthma: a study in prognosis of 1000 patients. Thorax 1962;17:183-9.

15 Wilken-Jensen K. Prognosis of asthma during childhood. Acta Paediatr (Uppsala) 1963;140S:90-2.

16 Kraepelien S. Prognosis of asthma in childhood with special reference to pulmonary function and the value of specific hyposensitization. Acta Paediatr (Uppsala) 1963;140S:923.

17 Aas K. Prognosis for asthmatic children. Follow-up on children who have not had optimal examination and treatment. Acta Paediatr (Uppsala) 1963;140S:87-8.

18 Ryssing E, Flensborg E. Prognosis after puberty for $\mathbf{4 4 2}$ asthmatic children examined and treated on specific allergologic principles. Acta Paediatr (Stockholm) 1963;52:97gologic.

19 Barr LW, Logan GB. Prognosis of children having asthma. Pediatrics 1964;35:856-60.

20 Buffum W, Settipane G. Prognosis in asthma in children. Am $\mathcal{F}$ Dis Child 1966;112:214-7.

21 Johnstone DE. A study of the natural history of bronchial asthma in children. Am $\mathcal{F}$ Dis Child 1968;115:213-6.

22 Johnstone DE, Dutton A. The value of hyposensitization therapy for bronchial asthma in children - a 14-year study. Pediatrics 1969;42:793-802.

23 Williams $\mathrm{H}$, McNicol KN. Prevalence, natural history and relationship of wheezy bronchitis and asthma in children. relationship of wheezy bronchitis and asthma in

$24 \mathrm{McNicol} \mathrm{KN}$, Williams HB. Spectrum of asthma in children - I. Clinical and physiological components. BMF 1973;4: 7-11.

25 Mukoyama T, Baba M, Kitajima Y, Iwatake K, Watanabe A, Kabasawa $\mathrm{Y}$, et al. The prognosis of asthma in children. Acta Paediatr fap 1975;17:23-9.

26 Baum WF. Katamnestische Untersuchungen uber Beginn und Verlauf des Asthma bronchiale im Kindesalter. Kinderarztliche Praxis 1975;43:510-6.

27 Blair H. Natural history of childhood asthma. 20-year follow-up. Arch Dis Child 1977;52:613-9.

28 Martin AJ, McLennan LA, Landau LI, Phelan PD. The natural history of childhood asthma to adult life. $B M F$ 1980;280:1397-400

29 Martin AJ, Landau LI, Phelan PD. Lung function in young adults who had asthma in childhood. Am Rev Respir Dis 1980;122:609-16.

30 Martin AJ, Landau LI, Phelan PD. Natural history of allergy in asthmatic children followed to adult life. Med $\mathcal{F}$ Aust 1981;2:470-4.

31 Martin AJ, Landau LI, Phelan PD. Predicting the course of asthma in children. Aust Paediatr f 1982;18:84-7.

32 Foucard T, Sjöberg O. A prospective 12-year follow-up study of children with wheezy bronchitis. Acta Paediatr Scand 1984;73:577-83.

33 Cserhati E, Mezei G, Kelemen J. Late prognosis of bronchial asthma in children. Respiration 1984;46:160-5.

34 Nishima S, Inamitsu T, Shibata R, Kanegae N. Clinical manifestations, pulmonary function and prognosis in asthmatic children: a comparison between groups with a high and a low serum IgE level. Acta Paediatr fap 1987;29: $639-44$.

35 Jönsson JA, Boe J, Berlin E. The long-term prognosis of childhood asthma in a predominantly rural Swedish childhood asthma in a predominantly rural

36 Friberg S, Bevegárd S, Graff-Lonnevig V. Asthma from childhood to adult age. A prospective study of 20 subjects with special reference to the clinical course and pulmonary function. Acta Paediatr Scand 1988;77:424-31.

37 Østergaard PAA. A prospective study on non-IgE-mediated asthma in children. Acta Paediatr Scand 1988;77:112-7.

38 Kelly WJW, Hudson I, Raven J, Phelan PD, Pain MCF Olinsky A. Childhood asthma and adult lung function. Am Rev Respir Dis 1988;138:26-30.

39 Friberg S, Bevegård S, Graff-Lonnevig V, Hallback I. Asthma from childhood to adulthood. A follow-up study of 20 subjects with special reference to work capacity and pulmonary gas exchange. $\mathcal{f}$ Allergy Clin Immunol 1989;84: pulmonary 
40 Gerritsen J, Koëter GH, Postma DS, Schouten JP, Knol K. Prognosis of asthma from childhood to adulthood. $\mathrm{Am}$ Rev Respir Dis 1989;140:1325-30.

41 Nowak D, Wiebicke W, Magnussen H. Die prognose des asthma bronchiale im kindesalter. Monatschr Kinderheilkd 1989;137:8-12.

42 Kelly WJW, Hudson I, Phelan PD, Pain MCF, Olinsky A. Atopy in subjects with asthma followed to the age of 28 years. F Allengy Clin Immunol 1990;85:548-57.

43 Tuchinda M. Childhood asthma in Thailand. Acta Paediatr fap 1990;32:169-72.

44 Aberg N, Engström I. Natural history of allergic diseases in children. Acta Paediatr Scand 1990;79:206-11.

45 Gerritsen J, Koëter GH, de Monchy JGR, Knol K. Allergy in subjects with asthma from childhood to adulthood. $\mathcal{F}$ Allergy Clin Immunol 1990;85:116-25.

46 Gerritsen J, Koëter GH, de Monchy JGR, van Lookeren Campagne JG, Knol K. Change in airway responsiveness to inhaled house dust from childhood to adulthood. $\mathcal{F}$ Allergy Clin Immunol 1990;85:1083-9.

47 Roorda RJ, Gerritsen J, van Aalderen WMC, Knol K. Influence of a positive family history and associated allergic diseases on the natural course of asthma. Clin Exp Allengy 1992;22:627-34

48 Kaplan BA, Mascie-Taylor CGN. Predicting the duration of childhood asthma. F Asthma 1992;29:39-48.

49 Kokkonen J, Linna $O$. The state of childhood asthma in young adulthood. Eur Respir $\mathcal{F}$ 1993;6:657-61.

50 Roorda RJ, Gerritsen J, van Aalderen WMC, Knol K. Skin reactivity and eosinophil count in relation to the outcome of childhood asthma. Eur Respir f 1993;6:509-16.

51 Roorda RJ, Gerritsen J, van Aalderen WMC, Schouten JP, Veltman JC, Weiss ST, et al. Risk factors for the persistence of respiratory symptoms in childhood asthma. Am Rev Respir Dis 1993;148:1490-5.

52 Roorda RJ, Gerritsen J, van Aalderen WMC, Schouten JP, Veltman JC, Weiss ST, et al. Follow-up of asthma from childhood to adulthood: influence of potential childhood risk factors on the outcome of pulmonary function and bronchial responsiveness in adulthood. $f$ Allengy Clin Immunol 1994;93:575-84.

53 Oswald H, Phelan PD, Lanigan A, Hibbert M, Bowes G, Olinsky A. Outcome of childhood asthma in mid-adult life. $B M \mathcal{F}$ 1994;309:95-6.

54 Kjellman K, Hesselmar B. Prognosis of asthma in children: a cohort study into adulthood. Acta Paediatr 1994;83: 854-61.

55 Mazon A, Nieto A, Nieto FJ, Menendez R, Boquete $M$, Brines J. Prognostic factors in childhood asthma: a logistic regression analysis. Ann Allergy 1994;72:455-61.

56 Godden DJ, Ross S, Abdalla M, McMurray D, Douglas A, Oldman D, et al. Outcome of wheeze in childhood. Symptoms and pulmonary function 25 years later. $A m \mathcal{F}$ Respir Crit Care Med 1994;149:106-12.

57 Jenkins MA, Hopper JL, Bowes G, Carlin JB, Flander LB, Giles GG. Factors in childhood as predictors of asthma in adult life. $B M \mathcal{F}$ 1994;309:90-3.

58 Peckham C, Butler N. A national study of asthma in childhood. $\mathcal{F}$ Epidemiol Community Health 1978;32:79-85.

59 Anderson HR, Bland JM, Patel S, Peckham C. The natura history of asthma in childhood. 7 Epidemiol Community Health 1986;40:121-9.

60 Bronniman S, Burrows B. A prospective study of the natura history of asthma. Remission and relapse rates. Chest 1986; 90:480-4.

61 Aberg N, Engström I. Natural history of allergic diseases in children. Acta Paediatr Scand 1990;79:206-11.

62 Radford PG, Hopp RJ, Biven RE, Degab JA, Bewtra AK Townley RG. Longitudinal changes in bronchial hyperresponsiveness in asthmatic and previously asthmatic children. Chest 1992;101:624-9.

63 Ferguson AC. Persisting airway obstruction in asymptomatic children with asthma with normal peak expiratory flow rates. $¥$ Allergy Clin Immunol 1988;82:19-22.

64 Cooper DM, Cutz E, Levison H. Occult pulmonary abnormalities in asymptomatic asthmatic children. Chest 1977;71:361-5.

65 Blackhall $M$. Ventilatory function in subjects with childhood asthma who have become symptom free. Arch Dis Child 1970;45:363-6.

66 Cade JF, Pain MCF. Pulmonary function during clinical remission of asthma. How reversible is asthma? Aust NZ f Med 1973;3:545-51.

67 Strachan DP. The prevalence and natural history of wheezing in early childhood. $f R$ Coll Gen Pract 1985;35:182-4

68 Peat JK, Salome CM, Toelle BG, Bauman A, Woolcock AJ. Reliability of a respiratory history questionnaire and effect of mode of administration on classification of asthma in children. Chest 1992;102:153-7.

69 Barbee RA, Kalterborn W, Lebowitz MD, Burrows B Longitudinal changes in allergen skin test reactivity in a community population sample. $f$ Allergy Clin Immunol 1987;79:16-24.

70 Kjellman B, Dalén G. Long-term changes in inhalant allergy in asthmatic children. Aust Paediatr $\Im$ 1986;41:351-6.
71 Broder I, Barlow PP, Horton RJM. The epidemiology of asthma and hay fever in a total community. Tecumseh Michigan. II. The relation between asthma and hay fever. f Allengy 1962;44:524-31.

72 Kuzemko JA. Natural history of childhood asthma. $\mathcal{F}$ Pediatr 1980;97:886-92.

73 Hopp RJ, Townley RG, Biven RE, Bewtra AK, Nair NM. The presence of airway reactivity before the development of asthma. Am Rev Respir Dis 1990;141:2-8.

74 Jones A. Asymptomatic bronchial hyperreactivity and the development of asthma and other respiratory tract illnesses in children. Thorax 1994;49:757-61.

75 Clough JB. Holgate ST. The natural history of bronchial hyper-responsiveness. Clin Rev Allergy 1989;7:257-79.

76 Morikawa A, Mochizuki H, Shigeta M, Tokuyama K, Kuroume T. Age-related changes in bronchial hyperreactivity roume T. Age-related changes in bronchial hyperreactivity

77 Woolcock AJ, Salome CM, Keena VA. Reducing the severity of bronchial responsiveness. Am Rev Respir Dis 1991;143: S75-7.

78 Jones RHT, Jones RB. Ventilatory capacity in young adults with a history of asthma in childhood. $B M f$ 1966;2:976-8.

79 Duiverman EJ, Clément J, van de Woestijne KP, Neijens HJ, van de Bergh ACM, Kerrebijn KF. Forced oscillation technique; reference values for resistance and reactance over a frequency spectrum of $2-26 \mathrm{~Hz}$ in healthy children aged 2.3-12.5 years. Bull Eur Physiopathol Respir 1985;21: $171-8$.

80 Barnes PJ, Cuss FMC. Biochemistry of airway smooth muscle. Bull Eur Physiopathol Respir 1986;22(Suppl 7): 191-200.

81 Burrows B. Distribution of allergy in the general population. In: Sluiter HJ, van der Lende R, Gerritsen J, Postma DS, eds. Bronchitis IV. Fourth international symposium, Assen, Royal van Gorcum, 1989;3-10.

82 Hopp RJ, Bewtra AK, Nair NM, Watt GD, Townley RG. Methacholine inhalation challenge studies in a selected pediatric population. Am Rev Respir Dis 1986;134:994-8.

83 Sears MR, Jones DT, Holdaway MD, Hewitt CJ, Flannery EM, Herbison GP, et al. Prevalence of bronchial reactivity to inhaled methacholine in New Zealand children. Thorax 1986;41:283-9.

84 Peat JK, Britton WJ, Salome CM, Woolcock AJ. Bronchial hyper-responsiveness in two populations of Australian schoolchildren. II. Relative importance of associated factors. Clin Allergy 1987;17:283-90.

85 Kelly WJW, Hudson I, Phelan PD, Pain MCF, Olinsky O. Childhood asthma in adult life: A further study at 28 years of age. $B M \mathcal{F} 1987 ; 294: 1059-62$.

86 Jenkins MA, Hopper JL, Bowes G, Carlin JB, Flander LB, Giles GG. Factors in childhood as predictors of asthma in adult life. $B M 7$ 1994;309:90-3.

87 Weller $\mathrm{HH}$, van der Staeten $\mathrm{M}$, Vermeulen A, Orie NGM Hormonal pattern in bronchial asthma. Scand $\mathcal{J}$ Respir Dis 1968:49:163-84.

88 Murray AB, Morrison BJ. Passive smoking by asthmatics: Its greater effect on boys than on girls and on older than on younger children. Pediatrics 1989;84:451-9.

89 Tager IB. Passive smoking - bronchial responsiveness and atopy. Am Rev Respir Dis 1988;138:507-9.

90 Sherrill DL, Lebowitz MD, Knudson RJ, Burrows B. Smoking and symptom effects on the curves of lung function growth and decline. Am Rev Respir Dis 1991;144:17-22.

91 growth and decline. Am Rev Respir Dis 1991;144:17-22. Duiverman EJ, Pocock SJ, Kerrebijn KF, et al. Effects of 22 months treatment with inhaled corticosteroids and/or beta-2-agonists on lung function airway responsiveness and symptoms in child

92 Van Essen-Zandvliet EEM, Hughes MD, Waalkens $H J$, Duiverman EJ, Kerrebijn KF, and the Dutch Chronic Non-Specific Lung Disease Study Group. Remission of childhood asthma after long-term treatment with an inhaled corticosteroid (budesonide). Can it be reached? Eur Respir ₹ 1994;7:63-8.

93 Waalkens HJ, van Essen-Zandvliet EEM, Hughes MD, Gerritsen J, Duiverman EJ, Knol K, et al. Cessation of long-term treatment with inhaled corticosteroid (budesonide) in children with asthma results in deterioration. Am Rev Respir Dis 1993;148:1252-7.

94 Agertoft L, Pedersen S. Effects of long-term treatment with an inhaled corticosteroid on growth and pulmonary function in asthmatic children. Respir Med 1994;88:37381.

95 König P. The effect of drug therapy on long-term outcome in childhood asthma. Do the international guidelines improve long-term outcome? Eur Respir 7 1994;S108:A546.

96 Speight ANP, Lee DA, Hey EN. Underdiagnosis and undertreatment of asthma in childhood. BMF 1983;286:1255-8.

97 Martin AI, andau at age 21: the patient and his disease. $B M \mathcal{F} 1982 ; 284$ : at age $380-2$.

98 Levison HS, Collins-Williams C, Bryan AC, Reilly BJ, Orange RP. Asthma: current concepts. Pediatr Clin North Am 1974;21:951-65. 